University of Nebraska - Lincoln

DigitalCommons@University of Nebraska - Lincoln

\title{
The Welfare Effects of Erosion Controls, Banning Pesticides, and Limiting Fertilizer Application in the Corn Belt: Comment
}

Clayton Ogg

USDA Natural Resource Economics Division

Follow this and additional works at: https://digitalcommons.unl.edu/usdaarsfacpub

Part of the Agricultural Science Commons

Ogg, Clayton, "The Welfare Effects of Erosion Controls, Banning Pesticides, and Limiting Fertilizer Application in the Corn Belt: Comment" (1978). Publications from USDA-ARS / UNL Faculty. 827. https://digitalcommons.unl.edu/usdaarsfacpub/827

This Article is brought to you for free and open access by the U.S. Department of Agriculture: Agricultural Research Service, Lincoln, Nebraska at DigitalCommons@University of Nebraska - Lincoln. It has been accepted for inclusion in Publications from USDA-ARS / UNL Faculty by an authorized administrator of DigitalCommons@University of Nebraska - Lincoln. 


\title{
The Welfare Efiects of Erosion Controls, Banning Pes- ticides, and Limiting Fertilizer Application in the Corn Belt: Comment
}

\author{
Clayton $\mathbf{O}_{\text {zg }}$
}

The recent Journal work by C. Robert Taylor and Klaus Frohberg (TF) was an impressive study from the standpoint of both the enengy and imagination that must have gone into the model and the practical implications conceming the welfare effects of nonpoint pollution abatement. Yet, it appears that costs of nutrient management were considerably overestimated in the light of a number of experiments using techniques for controlling nutrient losses through proper timing of nitrogen fertilizer applications. Therefore, the model may have failed to represent the most cost effective techniques for reducing nitrogen pollution.

This failure 10 minimize costs appears to be the implication of Comell publications by Bouldin. Reid, and Lathwell: and Lathwell, Bouldin, and Reid, who also cite supporting data representing areas in the Midwest and much of the rest of the country as well. By comparing the optimal fertilizer applications from the TF optimum application rates for high yielding com with the optimum implied by Bouldin's fertilizer response curve, the apparent low level of management available in the linear programming model can be demonstrated. In the TF model (p. 29). 156 pounds of nitrogen were required to obtain an optimum yield for a specific price ratio and level of soil productivity. Given the same level of soil productivity and price ratio. Bouldin's optimum fertilizer application for summer sidedress fertilizer was less than half of TF's is6 pounds, and yields were comparable. Although TF do not specify the timing or the method of fertilizer management that their model permits for reducing pol. lution, Lathwell, Bouldin, and Reid cite fourteen Nebraska experiments (as described by Olson. Dreier, Thompson. Frank, and Grabouski) which suggest that applications in the 160-pound range are required to obtain optimum yield under a fall plow-down application technology. Again, summer sidedress produces the same yield from 80 pounds of nitrogen. During the years when fertilizer was relatively inexpensive, many farmers and the fer.

Charton W. Ore is en nericulturn coonomist with the Natural Resource Economics Divition. Economics. Stutitics. and Cosperivives Service, U.S. Departunen of Apriculuure.

The views expressed are those of the author and do not neces. serily represent those of the U.S. Depertinent of Apriculkure. Toe wothor is criveful for belphul comments of Mart $R$. Beiley. Lee $A$. Christemen. John E. Honcetier, and en anonyonous reviewer. tilizer industry still took advantage of the convenience of applying fertilizer in the fall or spring, partly to avoid risk that wet weather would interfere with sidedress applications. However, Bouldin. Reid. and Lathwell argue that rainy weather is precisely when economic effects of nitrate losses will be the most damaging.

Sidedressed nitrogen is used more effectively by plants than fall or spring plow-down because less is leached by rains. This is largely documented through measurement of the quite substantial differences in nitrogen content of above-ground dry matter (Bouldin. Reid, Lathwell).

Since TF simply designate nitrogen reduction as their model's "best management" technology for obtaining optimum yields under pollution control restraints. One can only infer why the estimates of loss in consumer surplus are so large. Failure to allow use of best technologies available can. of course, have a large impact on the model's policy implications.

[Received December 1977; revision accepted March 1978.1

\section{References}

Bouldin, D. R., W. S. Reid, and D. J. Lathwell. "Fertilizer Practices Which Minimize Nutrient Loss." Agricultural Wastes: Principles and Guidelines for Pracrical Solutions. Proceedings of Comell Univer. sity Conference on Agricuttural Waste Management. Syracuse, 1971.

Lathwell, P. J., D. R. Bouldin, and W. S. Reid. "Effects of Nitrogen Fentilizer Application in Agriculture." Relationship of Agriculture so Soll and Water Polltw. IIon. Proceedines of Comell University Conference on Agricultural Waste Management. Syracuse, 1970.

Oison, R. A.. A. F. Dreier, C. Thompson. K. Frank, and P. H. Grabouski. Using Fersilizer Nitrogen Effecilvely on Grain Crops. Netraska Agr. Exp. Sta. SB 479. 1964.

Taylor. C. Rober. and Klaus Frohberg. "The Welfare Effects of Erosion Controls. Banning Pesticides, and Limiting Fertilizer Application in the Com Belt." Amer. J. Agr. Econ. S9(1977):25-36. 